\title{
MOTHER-TONGUE INTERFERENCE IN LEARNING ENGLISH IN ENGLISH MEETING CLUB
}

\author{
Rahayu $^{1}$, Nurfajriah Basri ${ }^{2}$ \\ Sawerigading University of Makassar ${ }^{1,2}$ \\ *rahayumahsyar.unsa@gmail.com
}

\begin{abstract}
Interference is a phenomenon that occurs in a society when learning a new language and bilingualism is one of the causes why interference is. Interference occurs mostly because the speakers who have more than one language used to interact with one another. This study aimed to describe the kind of interference errors made by learners of English in English Meeting of disorders caused by the mother tongue. This study used qualitative method which total subject was taken from participants of English Meeting consists of 10 learners that was taken by random sampling. Instrument of data collection used audio recording which was converted into transcription. The results showed that interference errors committed by English language learners' is generally influenced to phonetic refers to speech sounds, lexical interference to the level of words and grammar disorder refers to the rules of grammar in language. This is due to the fact that the speaker Indonesia experienced a huge obstacle when trying to use English as the target language as first language learners have mastered. The source of the difficulties is based on the level difference between the Indonesian system and the English system
\end{abstract}

Keywords: English Meeting Club, Error Analysis, Mother-Tongue Interference

\section{INTRODUCTION}

Learning a second language is not easy to be mastered because there will be many errors that occur both in terms of spelling, pronunciation, vocabulary and grammar. However, it is entirely due to the difference between the learner's mother tongue and the language he is learning. Speaker or writer who failed in transferring the items or structures that are different in both of language is referred to as negative transfer or interference. According to Zaim (2002) said that interferences happens because the learner makes the similarity between the sentence in English as target language and the sentence in Indonesian as mother tongue that he has mastered.

Kesmez (2014) conducted an analysis of the 11 interference errors of Turkish University Learners in their written productions. He concluded that these errors stemming from Turkish were initially categorized into four major categories; morphological, lexical, syntactic and orthographic and then those mentioned major categories were also divided 
into sub-categories. According to the results, the lexical category-including word for word translation errors, wrong use of uncountable nouns and verb errors-constitutes the largest group among the interference errors in the writing productions of learners. The other interference errors were located in syntactic, morphological, and orthographic categories respectively.

Bada (2001) stated that native language influence on the production of English sounds by Japanese learners. From result his research he concluded that some sounds were found to pose some difficulty of production, and that the difficulty is attributable to NL, others were produced with much less difficulty due to the already-present NL system of phonology. Other non-interlingual learning strategies were also observed to be employed by the learners in producing English sounds.

Baloch (2013) conducted his research that L1 (Arabic) interference in learning L2 (English): an analysis of English spelling used by Arabic speakers at undergraduate level. After the careful analysis it can be concluded that the replacement of ' $b$ ' with ' $p$ ' and vice versa happens because of the mother tongue interference. Learners do not find ' $p$ ' in their mother tongue and they try to change it with the nearest letter in pronunciation in their mother tongue. As far omission and addition of ' $\mathrm{e}$ ' is concerned, it happens because we do not find rules for ' $\mathrm{e}$ ' in English spellings if it is places in the final position of a word.

Based on the observations, the researchers found that many English learners who use English in this case speaking, they have difficulty in switching their first language to a second language in addition the types of mistakes made by English learners were variously from phonetic, lexical or grammatical , voice and accent by novice learners.

So based on the problem statement above, the researcher formulate the research question as follows : "What type and cause of interference errors that are made by English learners in English meeting?. Objective of this research is to find out what type and cause of interference errors are made by English learners in English Meeting caused by mothertongue interference so that it can help english learners solve their problem in learning English speasially in speaking skill.

\section{METHODS}

This research is qualitative research. This qualitative research took a place in English Meeting (Roterdam Makassar) since the source of data was discussion activity in natural setting by using recording technique to analyze the efficiency data. Recording was used to know what type of intereference errors and interview to know what cause of interference error.

\section{Time and Location of the Research}

The location of the research was conducted at Rotterdam (English Meeting Club) and The time of research started from Desember 2020 until February 2021. 


\section{Data Source}

The subjects in this study are all of English learners in english club but the researcher focused on 10 participants who were chosen based randaomly. Object of research in this study is the performance of english learners at Rotterdam English Meeting.

\section{The Technique of Data Collection Observation}

The researcher conducted an observation to know whether English learners did interference errors in speaking english. The observation was to obtain data by simply watching the participants. It means that the researcher only watched the situation in the English meeting while doing recording in group discussion. The researcher observed the learning process but he did not interact or participate in the classroom.The emphasis during observation was on understanding the natural environment as lived by participants without altering or manipulating it.

Techniques for collecting data through observation are:

- The researcher wrote descriptions

The researcher makes written descriptions of the design data that want to find out.

- Voice recording

To make clear and validity the data of the research, allows the researcher to make a voice recording record. It makes it easy for the researcher to analyze the type of interference errors of English learners.

\section{Interview}

The researcher did the interview to English learners. It was given to know the cause interference errors by English learners. The open ended questions were designed to permit the respondents to feel completely free to express their answers as they wished, as detailed and complex, as long or as short as they felt are appropriate. These questions were intended to evoke fuller and richer responses and probe deeper. This way, unanticipated findings could be discovered. In this study used 10 questions to get the maximal result.

\section{The Technique of Data Analysis}

In this research, the researcher will analyze the data that has been obtained from the research site using analytical methods to study the results of the research. Includes what type of interference errors used by the teaching learners. After that, researchers will summarize the results of research into a conclusion. From that conclusion, the researcher will find out what the results of his research.

\section{RESULTS}

This part presents the findings of the research and the discussion of the research findings. The findings of the research cover the description of mother tongue interference in learning English in English Meeting club. The types of interference errors in learning English in English Meeting are as follows: 


\section{Phonetic Interference}

In phonological level, the problem of interference concerns the manner in which a speaker perceives and reproduces the sounds of one language in terms of another. This interference occurs in the speech of bilingual as a result of the fact that there are different elements in sound system between one language and another

In the present data, there are two examples were found in learners' errors in phonetic interference. The examples were taken from audio recording which it was formed of transcription data.

Extract 1: Two speakers in conversation

In first circle group

Speaker 1 : Ok, Move to..you

Speaker 3 : Ifyou ask me how important car for me. It s not really important for me@ because the first reason is because I don't have a car maybe@ then, I can go any by motorcycle. So if u ask me the such question I should say it is no really important for me and also I don't like to go by car because sometimes I feel bad when I go by car.

Speaker 1 : so that s no important for u right?

Speaker 3 :yes.

Extract 2 : Two speakers in conversation

In second circle group

Speaker 1 : okay, let's move to our sister. What is your name sister?

Speaker 4 : uni.

Speaker 1 : oke, uni.

Speaker $4 \quad:$...the advantages and the disadvantages. The advantages, of course, we can go to anywhere easily. And we can shorten our time to go to the place and the disadvantages, of course it will cause a traffic jam and also pollution not only not only in air but also the voice of the car. And also sometimes there is accident because of the car okay, I think that's the disadvantages of the car.

From the extracts above, it can be identified that extract (1)and (2) employed phonetic interference as learners' error . It can be showed when speaker 3 in extract (1) give an opinion. It was showed when speaker 3 spelt important by saying /impo'tent/. Based on Cambridge Dictionary, it should be /Im'pə..tant/. In same case, speaker 4 in extract (2) did the same errors in spelling words such as advantages and disadvantages by saying /ad'ventejis/ and /dis'ad'ventejis/. In fact, it should be spelt /ad'va:n.tId3/ and /.dis.ad'vain.tId3/. Both of extracts above shows that the learners' errors in spelling words in English is influenced by mother tongue (Indonesia) which the speakers use indonesian alphabet in saying English word. 


\section{Lexical interference}

(Lekova, 2010) Lexical interference occurs at the level of words. Interference at a lexical level provides for the borrowing of words from one language and converting them to sound more natural in another. This type of interference is divided into two types. The first is how the speaker fails considering the character of a word. The second type is interference caused by the lack of ability to express a concept using more words in English.

In the present data below, it had been found the learners' errors in lexical interference. The examples were taken from the transcription of members of English member club which were doing discussion.

Extract 3: Dialogue in two speakers in discussion activity

In first circle group

Speaker2 : according to me advantages with the car we can go in somewhere it is not feel hot and the what is the meaning barang barang Things or stuff we can easy to bring only that

Speaker1 : ok.disadvantages...[kekurangan]

Extract 4: Dialogue in two speakers in discussion activity

In first circle group

Speaker1 : just driving motorcycle. so it is no important for $u$ ?

Speaker5 : important does not mean every day, every time, every moment you will use car. important means someday $u$ will use it.-

Speaker1 : but she said it no really important because she ..how often you go back to your hometown?

Speaker6 : just one year two time

By looking at both of extracts above, it can be identified that extract (3) and (4) categorized as lexical interference. It can be showed when speaker 2 in extract (3) starting his sentence by saying according to me to represent his own opinion. The expression is usually used as disclaimer. In same case, speaker 6 in extract 4 said two time to express how often something happen. The expression still refers to mother tongue which in English should be adverb of frequency. It shows that the learners' errors in using words in English are caused by speakers fail considering the character of a word and their choice from all the possible meanings is inappropriate

Extract 5: Dialogue in two speakers in discussion activity

In second circle group

Speaker 3 : I don't agree we must change maybe the question. I will be our government when stop the producing . they maybe...yeah mengurangi kali yah. Reduce the producing of car for example tax high export new car and if one family want to buy second car its rule the second highest tax so that want to buy second car because the tax very expensive .....[continue conversation]...... 
Speaker 5 : I think its no easy when money talks. of course government will get much advantages from produce many cars every year[yeah]

In extract 5 above, speaker 5 commented what the speaker 3 said by saying money talks". The idiom is used to express that money has power to influence people. This is categorized as lexical interference in second type which caused by the lack of ability to express a concept using more words in English, this last subcategory generally is the case of a literal translation of an idiom.

\section{Grammatical Interference}

Grammatical interference is defined as the first language influencing the second in terms of word order, such as; in using of pronouns and determinants, tense and mood. Based on Wienriech in (Martanti, 2011) grammatical interference is divided into three types. The first type is interference belongs in Morphology. The second type is grammatical relations which relates to Syntax, namely word order. The last type is Interference relates to functions or meanings of grammatical forms.

In the present data below, it had been found the learners' errors in grammatical interference. The examples were taken from the transcription of members of English member club which were doing discussion.

Extract 6: Dialogue in two speakers in discussion activity

In second circle group

Speaker 1 : okay, move to the next, our brother. How important car for you?

Speaker 2 : how important car here, as we know that car always bring us wherever we wanna go. Like we come here by car. then we can go to our village if we want to have having what is the vision we should in drive driving car together car is very important for us but there is a negative effect of the car. So...

Speaker 1 : so?

Speker 2 : car is important hehe

Extract 7: Dialogue in two speakers in discussion activity

In third circle group

Speaker 3 : I like your comment

Speaker 4 : Yess, I agree you statement

Speaker 5 : Ohh you have statement same with me, ok ok. Why you agree with me, I think

Speaker 3 : Ilike your comment maidas

Speaker 4 : Really

After looking at the extracts above, it can be identified that extract (6) and (7) categorized as grammatical interference. It can be showed when speaker 2 in extract (6) said "bring" which it is verb. According to the rule of simple present tense, verb after subject is added by s or es. In same case, speaker 4 in extract 7 said "you" to express possessive. In fact, "you " to represent possessive can use your or yours. Both of extracts 
above shows interference occurs because the transfer of morphemes from the first language or mother tongue in target language usage. This is called as grammatical interference first type.

Extract 8: Dialogue in two speakers in discussion activity

In first circle group

Speaker5 : How far you can walk?-

Speaker7 : I think one kilometer.

Speaker1 : But in Indonesia is so strange go to walking actually. It is different with other country...the country provides the line. So we can walk around the city and we feel comfort they provide really good line. it is different with our country always seem really rush, quite and walking is not best choice for us to go somewhere but driving motorcycle more better

In extract 8 above, speaker 5 asked a question by saying "How far you can walk?. It is included as statement which if it is a question should modal put before subject. The error is caused by first language influence to target language. The speaker tried to ask the question with using a statement sentence which it does not need an answer actually. This is called as the second type of grammatical interference which it relates to word order.

Extract 9: Dialogue in two speakers in discussion activity

In Third circle group

Leader : What about you?

Speaker $2 \quad$ :.. I think I think I choose use ee motor cycle, because if motor cycle faster and we can't come late to school, if we using car using car is slower than motor cycle, soo we come late to school. Yes, may just that.

In extract 9 above, leader asked a question to speaker 2 about his opinion. Then, Speaker 2 expressed his opinion by saying "motorcycle faster". It is called as nominal sentence which its predicate is to be (am ,is ,are). Those errors are caused by interference of mother tongue. Indonesian does not have "to be / auxiliary" like English. This interference relates to functions or grammatical meaning of language that occurs when a speaker identifies the morpheme or grammatical of first language and then use it in target language. So this is called as third type in grammatical interference. 
Table 1. Data display

\begin{tabular}{|c|c|c|c|}
\hline No & Interference types & Example & Extract \\
\hline \multirow[t]{2}{*}{1.} & Phonetic interference & how important car for me? & 1 \\
\hline & & the advantages and the disadvantages. & 2 \\
\hline \multirow[t]{4}{*}{2.} & Lexical interference & & \\
\hline & considering the character of a & according to me advantages with the car & 3 \\
\hline & word & just one year two time & 4 \\
\hline & $\begin{array}{l}\text { the lack of ability to express a } \\
\text { concept }\end{array}$ & I think its no easy when money talks & 5 \\
\hline \multirow[t]{5}{*}{3} & Grammatical interference & & \\
\hline & Morphology & as we know that car always bring us & 6 \\
\hline & & Yess, I agree you statement & 7 \\
\hline & Syntax, word order & how far you can walk?- & 8 \\
\hline & $\begin{array}{l}\text { functions or meanings of } \\
\text { grammatical forms }\end{array}$ & motor cycle faster & 9 \\
\hline
\end{tabular}

\section{DISCUSSIONS}

The previous studies described above are similar to the author's research in the field of interference. The main difference from the previous research is that it discusses interference errors in speech. Dulay et al., (1982) distinguish interference into two parts, namely psychological and sociolinguistic. Psychological refers to the influence of old habits when new ones are learned, whereas sociolinguistics refers to the interaction of language when two language communities are in contact. Therefore, based on the author's experience and observations, learners often have difficulty in mastering a second language because of interference, which is influenced by old habits, popular with mother tongue and bilingual contact in society.

In this study, the object of research is the interference used by English learners in the English meeting club. The activity of the English meeting is discussion. The discussion between English learners about the English meeting was conducted in English which was then transcribed to obtain detailed interference data. The discussion in this English meeting was formed as a sharing forum in an outdoor setting. Each learner can express his opinion in speaking; it means that each learner is a speaker but it is done in turns. Speakers who are bilingualism then fail to transfer different items or structures in both languages which is referred to as negative transfer or interference. 
Negative interference or transfer is the effect of language learners' first language on the production of the language they are learning. That is, the speaker's first language influences the second language. Inference errors made by English learners refer to three types of interference, namely phonological, lexical, and grammatical interference according to what has been stated by lekova (2010). The three types of interference are influenced by the mother tongue (Indonesia) which mostly produces sounds, words or sentences following the Indonesian language system. English learners who want to master English are considered to be able to reduce errors by learning more of the target language system.

Interference errors made by English learners are generally influenced by phonetics referring to speech sounds, lexical refers to the word level and grammatical interference refers to the grammatical rules in the language. . This is because Indonesian speakers experience considerable obstacles when trying to use English as the target language that has been mastered by first language learners. The source of difficulty is based on the difference in level between the Indonesian system and the English system.

In addition, to minimize interference errors made by English learners, especially in English Meetings, there are several ways that English learners themselves can try. First, as long as speakers are bilingual, they must arrange or arrange or spell carefully the sentences they want to say. Second, the addition of target language vocabulary is also important to reduce interference. Then the third is the speaker must know the standard pattern that will be used in compiling the target language (English).

The three methods above can be very effective if applied properly. English learners who really want to master English can follow this strategy because as we know that in society, especially in English meetings, there are no teachers who will teach us exactly how to master English. Sharing knowledge, experiences and opinions can be found there, English meeting.

\section{CONCLUSION}

Interference is a common phenomenon for English language learners. It is very difficult to avoid interference in learning English because the first language for novice learners has a dominant role, so reducing interference errors in English is very difficult. However, from the results of this study, several things can be obtained that are very helpful for English learners, especially for those who choose English Club as a learning place namely :

1. English learners at meeting club, especially Rotterdam, can easily find out what types of mistakes that they made and what the causes of intereference errors so that they can reduce their mistakes.

2. English learners can be selective in choosing English meeting club so that learning abilities can be maximized because in English Club there are no teachers who will guide 
us precisely how to master in English. Sharing knowledge, experiences and opinions can be found there at the English meeting.

3 . For further research, this can be used as a reference to help solve the problem of interference errors, speaking and other multibilingual problems commonly experienced by novice learners

\section{ACKNOWLEDGMENT}

I would like to give a great thanks to Prof. A Melantik Rampogading M.H, as the Rector of Sawerigading University of Makassar and Dean of Literature Faculty of Sawerigading University of Makassar, Dra.Mardiani M.Hum and all of the lecturer and friend that have helped to finish the research.

\section{REFERENCES}

Bada, E. (2001). Native language influence on the production of English sounds by Japanese learners. The Reading Matrix, 1(2), 15. . Retrieved from http://www.readingmatrix.com/articles/bada/article.pdf

Baloch, S. S. (2013). L1 (Arabic) Interference in Learning L2 (English): an Analysis of English Spelling Used By Arabic Speakers At Undergraduate Level -a Case Study. European Scientific Journal, 9(16), 226-232.

Berthold, M., Mangubhai, F., \& Batorowicz, K. (1997). Bilingualism \& Multiculturalism: Study Book. Distance Education Centre. In University of Southern Queensland. Toowoomba, QLD.

Dulay, H.; Burt, M.; Krashen, S. (1982). Language Two. In New York. Oxford Univ. Press.

Ellis, R. (2008). The study of second language acquisition (2nd ed.). In New York. Oxford University Press.

Kesmez, A. (2014). An analysis of the L1 interference errors of Turkish university students in their written productions. The Journal of Academic Social Science Studies, 34, 395402.

Lekova, B. (2010). Language Interference and Methods of Its Overcoming in Foreign Language Teaching. Trakia Journal of Sciences, 8, 320-324.

Lott, D. (1983). Analysing and counteracting interference errors. ELT Journal, 37/3, 256261.

Martanti, P. (2011). An analysis of grammatical interference in Articles of berani newspaper. In Jakarta. State Islamic University.

Weinreich U. (1963). Languages in contac: Findings and problems. In The Hague. Mounton \& Co. 
Vol.2, No. 3, July 2021

$e$-ISSN: 2723-4126

p-ISSN: 2776-8880

Zaim, M. (2002). Kesalahan Sintaksis dan Semantis dalam Terjemahan PembelajaranBahasa Inggris. In Padang. Universitas Negeri Padang Press. 